選択的胃迷走神経切離兼幽門洞切除術に㧍ける右胃大網動静脈

扣よび神経枝温存の意義について一臨床的検討一

\begin{tabular}{|c|c|c|c|c|c|c|c|}
\hline \multicolumn{8}{|c|}{ 新渴大学医学部外科教室第 1 講座 } \\
\hline 高桑 & 一喜 & 松原 & 要一 & 松尾 & 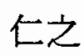 & 薛 & 康弘 \\
\hline 吉田 & 正弘 & 田宮 & 洋一 & 若桑 & 正一 & 筒井 & 光広 \\
\hline 加藤 & 知邦 & 三浦 & 宏二 & 武藤 & 輝一 & & \\
\hline
\end{tabular}

\title{
CLINICAL APPRAISAL OF THE OPERATIVE PROCEDURE WITH PRESERVATION OF THE RIGHT GASTROEPIPLOIC \\ NEUROVASCULAR PEDUNCLE IN ANTRECTOMY WITH SELECTIVE GASTRIC VAGOTOMY FOR CHRONIC DUODENAL ULCER
}

\author{
Kazuyoshi TAKAKUWA, Yoichi MATSUBARA, Hitoshi MATSUO, \\ Yasuhiro SETSU, Masahiro YOSHIDA, Yoichi TAMIYA, \\ Syoichi WAKAKUWA, Mitsuhiro TSUTSUI, Tomokuni KATO, \\ Koji MIURA and Terukazu MUTO \\ Department of Surgery, School of Medicine, University of Niigata
}

十二指腸潰瘍の外科的治療として選択的胃迷走神経切離兼幽門洞切除術を施行する際に，右胃大網 動静脈とこれに沿う神経枝を温存した13例を温存群, これらを切離して施行した16例を切離群とし, 両群間で術後の減酸率や術後早期の胃内容停滞について比較検討した。術後 3 カ月の减酸率は両群間 で差は認められなかった。術後 3 カ月までの胃内容停滞発生頻度は温存群で $15 \%$, 切離群で $63 \%$ であ り, 温存群で有意に少なかった $(\mathrm{p}<0.05)$. 従って, 選択的胃迷走神経切離兼幽門洞切除術を施行す る際に右胃大網動静脈とこれに沿う神経枝を温存することは, 術後早期の胃内容停滞を軽減するため に有用であると考えられた。

梙引用語：十二指腸漬瘍，選択的胃迷走神経切離兼幽門洞切除術，胃内容停滞，術後減酸率，右胃大網動静脈之 これに沿う神経枝温存

\section{I. 緒 言}

Farmer \& Smithwick ${ }^{1)}$, Edwards \& Herrington ${ }^{2)}$,

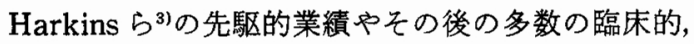
実験的研究により，迷走神経切離術 (迷切) 兼幽門洞 切除術 (幽切) は消化性潰瘍患者の胃分泌病態生理に 立脚した合理的な减酸手術であり，潰瘍再発が著しく 少なく，術後遠隔成績す極めて良好な優れた術式であ ることが立証され，現在では主に十二指腸潰瘍に対す る標準的手術の 1 つとして確立された感がある。

$<1984$ 年11月21日受理 $>$ 別刷請求先：高桑 一喜 干951 新渴市旭町通 1 番町 新潟大学医学部第 1 外 科
著者らの施設でも1961年より消化性潰瘍に対する選 択的手術4)の一環として迷切半胃切除術) (保存的胃切 除術河)を導入し，その成績についてこれまで数多く発 表してきた ${ }^{710)}$ ，当初は術前胃液酸度の高い胃潰場お よび十二指腸潰瘍症例を対象とし, 迷切は全幹迷切, 胃切除範囲を $50 \%$ 以下として施行してきたが，1964年 より迷切には選択的胃迷切（選胃迷切）をとり入れ， さらに術後遠隔成績の検討から，胃切除範囲を $40 \%$ 以 下7)して, 主に術前胃酸分泌能の高い十二指腸漬瘍 や幽門近接胃漬瘍症例に対して施行している ${ }^{10)}$. これ により, 選胃迷切兼幽切では, 潰瘍再発は認められず, 遠隔時の術後障害発生率も少ない優れた結果 ${ }^{11}$ が認め 
られている.

しかし，迷切兼幽切では術直後からしばらくの間で あるが，迷切にともなら胃内容停滞症状の高率に認め られることが唯一の欠点福である.そこで教室では, 新 田ら ${ }^{13)}$ の報告に基づき, 術後早期の胃内容停滞発現頻 度を減少させる目的で, 1981年より選胃迷切兼幽切を 施行する際に右胃大網動静脈とこれに沿ら神経枝を温 存する術式（本術式）を採用して実施している10)（図 1). 今回, 本術式と従来の右胃大網枝を切離する術式 での術後減酸率や術後早期の臨床症状について比較検 討したので報告する。.

\section{II. 対象および方法}

1981年より1983年末までに選胃迷切兼幽切が13例の 十二指晹潰瘍に対して施行された（Billroth I 法11例, Billroth II 法 2 例) が，これらの症例ではすべて右胃 大網動静脈とこれに沿ら神経枝を温存する術式が施行 され，これを“温存群”とした，1977年より1980年末 までに十二指腸漬湟に対して選胃迷切兼幽切の施行さ れた16例(Billroth I 法11例, Billroth II 法 5 例)を“切 離群”とし, 両群の術前術後の胃酸分泌能, 術後早期 の臨床症状について比較検討した。

術前, 術後の胃液検査は10分間隔の分割採取とし, テトラガストリン法とインスリン法を施行した。 テト ラガストリン法は，まず10分間隔で 60 分間基礎分泌液 を採取したのち，テトラガストリン $4 \gamma / \mathrm{kg}$ を筋注して 90 分まで採液した。インスリン法は，60分間の基礎分 泌採液後, レギュラーインスリン15単位を静注し120分 まで採液した。同時にインスリン静注前と静注後 15 ,
因 1 選択的胃迷切兼幽門洞切除術（1981年より施行 している術式)

1 ；迷切範囲， 2 ; 右胃大網動静脈とこれに沿う神 経枝温存, 3 ; 幽門洞切除

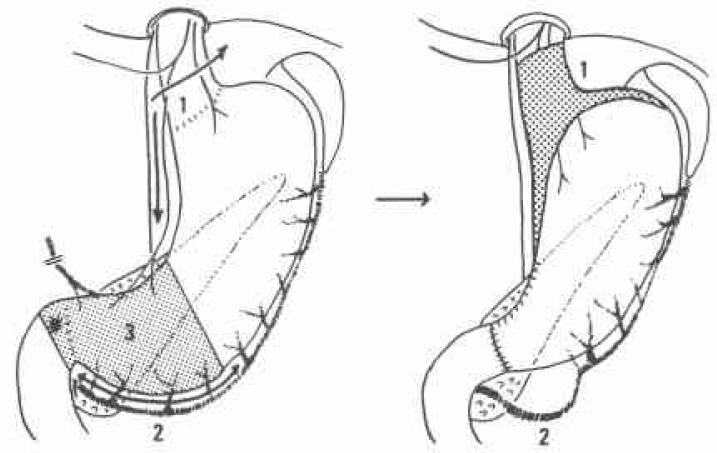

30，60，90，120分に採血して血糖が $50 \mathrm{mg} / \mathrm{dl}$ 以下と なっていることを確認した。なお，初期の症例では 15 分間隔で採液したものが含まれている。また，胃液酸 度の測定は全例 $\mathrm{pH}$ メーター法（pH 7.0 まで滴定）で 行った。

症状の判定に関しては, 腹部膨満がひと゚くても無症 状の場合もあることから，患者自身の訴えや医師もし くは看護婦の問いに対する答えのほかに術後 $2 \sim 3$ 週 に施行した胃透視所見を参考にした。

\section{III. 結 果}

1. 臨床像の比較

温存群 13 例中男性12例, 女性 1 例, 年齢は 10 歳から 56歳までで平均28.9歳であった，手術適応は難治性 6 例, 出血 2 例, 狭窄 5 例である。一方, 切離群 16 例中

表 1 選択的胃迷切兼幽門洞切除例の臨床像一温存群之切離群の比較一

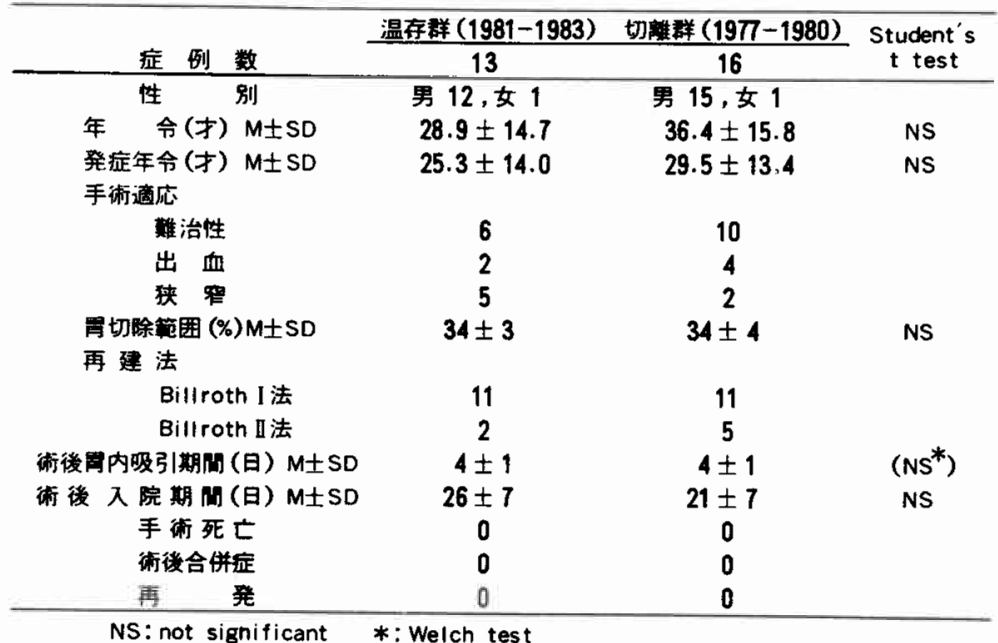


男性15例, 女性 1 例, 年龄は10歳から61歳までで平均 36.4歳であった。手術適応は難治性10例, 出血 4 例, 狭窄 2 例である。これらの症例に対して術前の胃液検 查結果より教室の手術術式選択基準 ${ }^{10}$ に沿って選胃迷 切兼幽切を施行した。胃切除範囲は両群とも35\%前後 であり，再建方法は手技的に可能な限り Billroth I 法 を施行することにしているので, 両群とも Billroth I が多くなっている.な浐, 温存群に 1 例, 切離群に 1 例，十二指腸断端閉鎖に際して catheter duodenostomyを併施した症例がある。術後のレビン管留置期 間は両群とも 4 日前後であった。 また, 両群ともほと んどの症例に metoclopramide (プリンペラン), sulpiride (ドグマチール), aclatonium napadisilate (アボビス)などの胃内容排出促進薬剤が投与されてい る. 術後入院期間は catheter duodenostomy を施行し た症例で39日，41日と長期間であったが，他の症例で は $2 \sim 3$ 週間である.

性別, 年齢, 手術適応, 胃切除範囲, 再建方法, 術 後のレビン管留置期間, 胃内容排出促進薬剂の使用状 況, 術後の入院期間は両群間に差は認められなかった。 また, 両群之も手術死亡, 術後合併症, 再発は認めら れない(表 1 ). 従って, 吻合部の器質的狭窄や腹腔内 の器質的あるいは機能的病変にともなら胃内容停滞症 例はない。

\section{2. 術前の胃酸分泌能の比較}

術前の胃液検査は全例に施行した，温存群では，基 礎酸濃度(BAC) $87 \pm 28 \mathrm{mEq} / \mathrm{L}$, 基礎酸分泌量(BAO) $8.5 \pm 4.9 \mathrm{mEq} / \mathrm{h}$ ，テトラガストリン刺激最高酸濃度 (MAC) $131 \pm 11 \mathrm{mEq} / \mathrm{L}$, 同最高酸分泌量 (MAO) $21.6 \pm 5.7 \mathrm{mEq} / \mathrm{h}$, インスリン刺激最高酸濃度（IMAC) $123 \pm 33 \mathrm{mEq} / \mathrm{L}$, 同最大酸分泌量 (I-PAO) $24.6 \pm 12.5 \mathrm{mEq} / \mathrm{h}$ であった。一方, 切離群では BAC $68 \pm 27 \mathrm{mEq} / \mathrm{L}, \mathrm{BAO} 7.6 \pm 6.6 \mathrm{mEq} / \mathrm{h}, \mathrm{MAC} 123 \pm 13$ $\mathrm{mEq} / \mathrm{L}, \mathrm{MAO} 22.3 \pm 10.2 \mathrm{mEq} / \mathrm{h}$, I-MAC $125 \pm 27$

表 2 術前の胃酸分泌能の比較

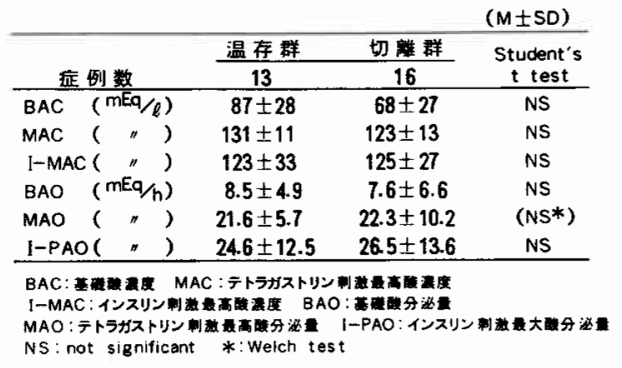

$\mathrm{mEq} / \mathrm{L}, \mathrm{I} \cdot \mathrm{PAO} 26.5 \pm 13.6 \mathrm{mEq} / \mathrm{h}$ であった. $\mathrm{BAC}$, $\mathrm{BAO}, \mathrm{MAC}, \mathrm{MAO}, \mathrm{I}-\mathrm{MAC}, \mathrm{I}-\mathrm{PAO}$ とす両群間で推計 学的に有意差は認められなかった（表 2 ).

3. 術後の胃酸分泌能々減酸率の比較

術後 3 力月の胃酸分泌能は, 温存群で BAC $23 \pm 19$ $\mathrm{mEq} / \mathrm{L}, \mathrm{BAO} 0.7 \pm 1.1 \mathrm{mEq} / \mathrm{h}, \mathrm{MAC} 48 \pm 26 \mathrm{mEq} / \mathrm{L}$, MAO $3.4 \pm 3.8 \mathrm{mEq} / \mathrm{h}, \mathrm{I}-\mathrm{MAC} 22 \pm 21 \mathrm{mEq} / \mathrm{L}, \mathrm{I} \cdot \mathrm{PAO}$ $0.5 \pm 0.6 \mathrm{mEq} / \mathrm{h}$ であり，減酸率はそれぞれ，73士25\%， $87 \pm 21 \% ， 64 \pm 19 \% ， 84 \pm 17 \% ， 83 \pm 18 \% ， 97 \pm 4 \%$ であった。一方, 切離群では BAC $22 \pm 28 \mathrm{mEq} / \mathrm{L}, \mathrm{BAO}$ $1.0 \pm 1.5 \mathrm{mEq} / \mathrm{h}, \mathrm{MAC} 38 \pm 33 \mathrm{mEq} / \mathrm{L}, \mathrm{MAO} 1.9 \pm$ $3.2 \mathrm{mEq} / \mathrm{h}, \mathrm{I}-\mathrm{MAC} 40 \pm 30 \mathrm{mEq} / \mathrm{L}$, I.PAO $1.4 \pm 1.5$

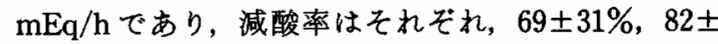
$23 \%, 68 \pm 26 \%, 89 \pm 15 \%, 70 \pm 21 \%, 95 \pm 4 \%$ $\%$ つ た。術後胃酸分洮能拈よび減酸率とも両群間に推計学 的有意差は認められなかった（表 3，4）。

なお，術後の Hollander 試験では，切離群で 3 例が early positive (Ross \& Kay) であった（表 5 ). これ は初期の症例で His 角周辺の迷切が不十分であった ものと思われる。

\section{4. 術後早期の臨床症状の比較}

術後経口摄取を開始してから 3 カ月までの主に胃内

表 3 術後 3 力月の胃酸分泌能の比較

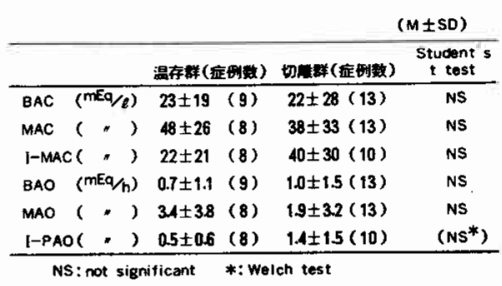

表 4 術後 3 カ月の減酸率 (\%)の比較

\begin{tabular}{|c|c|c|c|}
\hline & 温存群 (佂例数) & 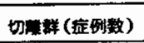 & $\begin{array}{l}\text { Student's } \\
\text { t test }\end{array}$ \\
\hline BAC & $73 \pm 25(9)$ & $69 \pm 31(13)$ & NS \\
\hline MAC & $64 \pm 19(8)$ & $68 \pm 26(13)$ & NS \\
\hline I-MAC & $83 \pm 18$ (8) & $70 \pm 21(10)$ & NS \\
\hline BAO & $87 \pm 21$ (9) & $82 \pm 23(13)$ & NS \\
\hline MAO & $84 \pm 17(8)$ & $89 \pm 15(13)$ & NS \\
\hline I-PAO & $97 \pm 4 \quad(8)$ & $95 \pm 4(10)$ & NS \\
\hline
\end{tabular}

表 5 Hollander 試験

\begin{tabular}{lccc} 
& \multicolumn{3}{c}{ (Ross \& Kay) } \\
\cline { 2 - 4 } 湜例数 & 8 & 10 & X $^{2}$ test \\
\cline { 2 - 4 } early positive & 0 & 3 & NS \\
late positive & 2 & 1 & NS \\
negative & 6 & 6 & NS \\
\hline NS: not significant & &
\end{tabular}


容排出遅延に基づく症状について比較検討した。一般 に, 選胃迷切兼幽切術後の胃内容停滞症状は一過性の あのが大半であり，日時が経過するとともに，患者自 身の食餉摂取方法の工夫や残胃の運動機能の改善によ り匡とんど消失する場合が多いしかし，今回の検討 では，食事を開始してから 3 カ月までの間に一過性に 認められたものもすべて含めて検討の対象とした。 た, 迷切兼幽切に対する教室の長年の経験から, 術後 の残胃透視所見で食物残渣が多量に認められる場合に は, 症状の有無に関保なく $1 \sim 2$ 回の胃洗浄を施行し て残渣を除去することがその後の経過に良好な結果を むたらすとの判断から積極的に胃洗浄を施行してい る. 事実, 対象症例の大多数は 3 力月以上経過すると 症状も卧とんど消失している。

術後早期の症状については, 温存群で食後の胃部も たれ感を訴克た症例は 3 例 (23\%) であり，呕気 2 例， 呕吐 3 例であった。また，胃透視所見で多量の食物残 渣を認め胃洗浄を施行した症例は 2 例（15\%）であっ たが， 2 例とも狭窄例に対して Billroth I 法で再建し た症例であった。一方，切離群で食後の胃部むたれ感 を訴えたものは10例（63\%）であり，呕気 4 例，呕昍 2 例であった。多量の食物残渣のため胃洗浄を要した 症例も10例（63\%）と高率であった。食後の胃部もた れ感に関しては, 温存群で少ない傾向を認め $(\mathrm{p}<$ 0.1 ，多量の食物残渣を認めた症例は温存群で有意に $(\mathbf{p}<0.05)$ 少なかった（表 6).

古くから, 迷切兼幽切に際しては, 特に胃切除範囲 が小さい場合, 迷切にともなら胃内容停滞を少しでも 軽減させるために Billroth II 法で再建している報告 が多い，自験例では，再建法別には，ほとんど差は認 められなかった（表 7).

なお， 2 年以上経過した遠隔時に胃透視や胃内視鏡 所見で残胃に多量の胃石を認めた症例が切離群に 4 例 あり，らち 3 例に対して, 胃洗浄や内視鏡的な胃石破 壊などの処置を必要とした。

\section{IV. 考 察}

胃酸分泌の脳相を迷切により，胃相を幽切により遮 断する迷切兼幽切は十分すぎるほどの減酸効果が得ら

表 6 術後早期の臨床症状の比較

\begin{tabular}{|c|c|c|c|}
\hline & 温存群 & 切難群 & \\
\hline 正列数 & 13 & 16 & $x^{2}$ test \\
\hline 無症状 & $9(69 \%)$ & $6(38 \%)$ & NS \\
\hline 嵝の同部むたん感 & $3(23 \%)$ & $10(63 \%)$ & $P<0.1$ \\
\hline 気 & 2 & 4 & NS \\
\hline 急 & 3 & 2 & NS \\
\hline 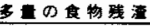 & $2(15 \%)$ & $10(63 \%)$ & $P<0.05$ \\
\hline
\end{tabular}

表 7 術後早期の臨床症状の比較（再建法別）

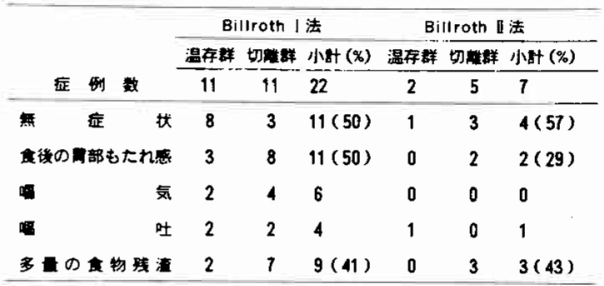

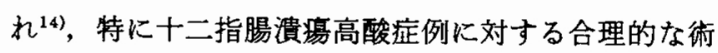
式である. 事実, 再発例は他の術式と比較して極端に 少ない，本邦の報告では，ほとんど再発例は認められ ず1015) 18), 迷奶研究会加入35施設に対してなされた了 ンケート調査の結果でも再発率は $0.5 \%$ あっった ${ }^{19)}$. た，欧米の文献でも迷切兼幽切の再発率は 0 $\sim 1.5 \%^{20) \sim 26)}$ と本邦の報告とほとんど変らず，幽門側 胃切除術の再発率が内外の報告で著しい相違を認め る27こととは対照的である。

迷切兼幽切が消化性潰瘍の外科的治療として登場し てから既に 40 年近くが経過し，その良好なる遠隔成績 にもかかわらず，いまだいくつかの問題点も存在する. それは, 全幹迷切を施行すると胃以外の藏器に分布す る迷走神経もともに切離されるため, 下峲, 消化吸収 障害, 胆石発生などの後遺症が認められること, 迷切 や幽切を完全に施行するための指標が不明確であるこ と, 迷切にともなら胃内容停滞が術後早期に高頻度に 認められることなどである.

全幹迷切による後遺症や迷切の完全性に関しては, 選胃迷切を施行することで泳解決されている28). た, 幽門洞部の完全切除に関しては, 胃切除範囲が極 端に少なく幽門洞部が残存する症例があると考えられ る Palumbo ら ${ }^{22)}$ の報告でも術後再発率が0.6\%であ り, 幽門洞部の不完全切除だけでは直接再発には結び つかないよらである。

迷切後の胃内容停滞に関しては，幽切を併施した場 合には, 術後早期に一過性に認められるだけで, 術後 3〜6力月すると残胃運動の回復とともにほとんど消 失するとの報告6)29)が多く, 李た, 胃内容停滞が直接再 発に結びっくことがないため，欧米の報告ではほとん ど問題にされていない，迷切兼幽切の術後早期の胃内 容停滞に関する報告をみると, 番場到は術直後より 2 週までの間にうっ滞症状を70例中 43 例 $(61.4 \%)$ 、認 め, 大西ら ${ }^{301}$ は症状と胃透視所見から検討すると 26 例 中22例 $(84.6 \%)$ に発生したと報告し, 渡部ら ${ }^{31}$ は63例 中13例 $(20.6 \%)$ であったと報告している. Jordan ${ }^{25)}$ 
表 8 術前狭窄例を除いた術後早期の臨床症状の比較

\begin{tabular}{|c|c|c|c|}
\hline & 温存群 & 切踓群 & \\
\hline 症 烈数 & 8 & 14 & $x^{2}$ test \\
\hline 無症状 & $7(88 \%)$ & $5(36 \%)$ & $P<0.1$ \\
\hline 食後の国部もたれ感 & 0 & $9(64 \%)$ & $P<0.025$ \\
\hline 富 気 & 0 & 4 & NS \\
\hline 吐 & 1 & 2 & NS \\
\hline 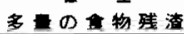 & 0 & $8(57 \%)$ & $P<0.025$ \\
\hline
\end{tabular}

は，選胃迷切兼幽切 Billroth I 法術後に97例中53例 (54.6\%)が術後10日目の胃透視で 2 時間以上のバリウ ム停滞を認めたと報告している. 胃内容停滞の評価に 関しては，報告者によりその criteria もさまざまであ るため，その発生率を報告者間で直接比較することは できないが，迷切兼幽切術後早期には，かなりの割合 で発生することがわかる，今回の検討です，従来の術 式では16例中10例 (63\%) に胃内容停滞が認められた.

選胃迷切兼幽切を施行する際に，右胃大網動脈を温 存したところ, 術後早期の胃内容停滞症状を軽減しえ たとの新田ら ${ }^{13)}$ の報告や，選択的近位胃迷切を施行す る際にその減酸率を高めるために右胃大網動脈に沿う 神経枝も切離するとの Rosati ら ${ }^{32)}$ の報告に接し, 選胃 迷切兼幽切例で右胃大網動静脈とこれに沿ら神経枝を 温存することにより, 減酸率を多少犠牲にしても, 残 胃の運動機能に対して良好な結果がえられるのではな いかとの考えから, 教室では1981年以来, 本術式を採 用して実施している. 今回の検討で, 本術式は従来の 術式と比較して, 減酸効果に差は認められず, 術後早 期の胃内容停滞症状を軽減しうることが明らかとなっ た. 特に, 本術式での不満足例は, 術前より幽門狭窄 のため胃が拡張した症例に対して Billroth I 法で再建 したものであり，狭窄例を除いた結果では，本術式の 優秀性は明らかである(表 8 ).

現在, 本術式の残胃運動に関して実験的に検討中で あるが，今後本術式の遠隔成續について検討していく 考えである。

\section{V. 結語}

十二指腸漬瘍症例に対して選択的胃迷走神経切離兼 幽門洞切除術を施行する際に, 右胃大網動静脈とこれ に沿う神経枝を温存することは, 術後早期の胃内容停 滞症状を軽減するために有用であると考えられた。

本論文の要旨は第13回迷切研究会, および第83回日本外 科学会総会に拈いて報告した。

\section{文献}

1) Farmer DA, Smithwick RH: Hemigastrectomy combined with resection of the vagus nerves. N Engl J Med 247 : 1017-1022, 1952

2) Edwards LW, Herrington JL: Vagotomy and gastro-enterostomy-vagotomy and conservative gastrectomy. A comparative study. Ann Surg $137: 873-883,1953$

3) Harkins HN, Schmitz EJ, Harper HP et al : A combined physiologic operation for peptic ulcer (Partial distal gastrectomy, vagotomy and gastroduodenostomy) A preliminary report. W J S O \& G $61: 316-319,1953$

4) 武藤輝一, 松木 久, 佐藤 㦑ほか: 胃・十二指腸 潰瘍に対する選択的手術。手術 $24: 1258-1266$, 1970

5）堺 哲郎, 番場道夫, 武藤輝一：胃・十二指腸潰場 に対する迷切半胃 (前庭) 切除例の価值 (近接成 績). 日外会誌 $63: 791-794,1962$

6）番場道夫：消化性漬瘍に対する“保存的”胃切除例 に関する臨床的, 実験的研究. 第 I 編, 臨床的観察. 日外会誌 $67: 108-158,1966$

7) 武藤輝一, 松木 久, 新田洋ほか：迷切の遠隔成 績一主之して幽門洞部切除十迷切について一. 外 科診療 $16: 644-648,1974$

8）武藤輝一：消化珄潰瘍に対する幽門洞部切除と選 択的迷切術. 外科診療 $17: 367-371,1975$

9）武藤輝一, 松原要一, 奈良井省吾はか：迷切除一そ の適応, 手術のコッ, 遠隔成績一. 外科治㞠 44 ： $48-60,1981$

10）武藤輝一：消化性潰瘍の外科一手術術式の選択之 その成績. 日外会誌 $83: 837-841,1982$

11）佐藤 蔽：慢性消化性潰瘍に対する術式選択とそ の成績について. 新潟医会誌 $90: 113-144,1976$

12）堺哲郎, 番場道夫, 武藤輝一：消化性溃湯に対す る迷走神経切断術の価値批判. 外科治療 9 ： $167-181 ， 1963$

13）新田 洋, 小林誠之助, 福田 稔注か：幽門洞切除 術兼選択的胃迷切術に於ける右胃大嘱動脈温存の 必要性. 新潟医会誌 $95: 192,1981$

14）松原要一, 奈良井省吾, 若桑正一ほか：潰場の再 発. 臨外 $36: 1703-1708,1981$

15）土屋周二, 杉山 貢：迷切後の遠隔成績. 臨外 $33: 213-221,1978$

16）三島秀雄, 近藤 孝, 大沢祐三ほか：遠隔成績から みた胃・十二指腸潰瘍の術式選択一减酸率と術後 障害について一。目臨外医会誌 $42: 380-387$, 1981

17）渡部洋三：十二指腸謴瘍に対する迷切術の遠隔成 績. 選択的胃迷走神経切離術十幽門洞切除術 $(\mathrm{SV}+\mathrm{A})$. 臨外 $38: 1610-1614,1983$

18）森岡恭彦，島津久明：消化管潰瘍に対する迷切術 の臨床的評価. 外科治療 $50: 127-134,1984$

19）山岸三木雄, 笠岡千孝, 山岸健男: 十二指腸潰痬手 術後の再発と胃酸分泌一迷切研究会加入 35 施設に 
対してなされたアンケート調査の結果から一、日 消外会誌 $16: 1433-1443,1983$

20) Farmer DA, Harrower HW, Smithwick RH : The choice of surgery in peptic ulcer disease. Am J Surg $120: 295-305,1970$

21) Herrington JL, Sawyers JL, Scott HW : A 25 . year experience with vagotomy-antrectomy. Arch Surg $106: 469-474,1973$

22) Palumbo LT, Sharpe WS: Distal antrectomy with vagectomy for duodenal uleer: Results in 611 cases. Ann Surg 182:610-616, 1975

23) Andersen D, $H \phi$ strup H, Amdrup E: The Aarhus county vagotomy trial. II. An interim report on reduction in acid secretion and ulcer recurrence rate following parietal cell vagotomy and selective gastric vagotomy. World J Surg 2 : 91-100, 1978

24) Goligher JC, Feather DB, Hall R et al: Several standard elective operatins for duodenal ulcer. Ten to 16 year clinical results. Ann Surg $189: 18-24,1979$

25) Jordan PH : An interim report on parietal cell vagotomy versus selective vagotomy and antrectomy for treatment of duodenal ulcer. Ann Surg 189:643-653, 1979

26) Koo J, Lam SK, Chan $P$ et al: Proximal gastric vagotomy, truncal vagotomy with drainage, and truncal vagotomy with antrectomy for chronic duodenal ulcer. A prospective, randomized controlled trial. Ann Surg 197 : 265-271, 1983

27）武藤輝一, 松木 久, 松原要一ほか：吻合部溃瘍之 その治療. 今日の臨床外科 $13: 141-155$, 東京, メジカル゚ュー社, 1979

28) Kennedy $T$ : Evaluation of selective vagotomy. In : Vagotomy on trial. Edited by AG Cox, J Alexander-Williams. London, William Heinemann Med Books Ltd, 1973, p85-96

29）大久保高明, 藤沢祥夫, 福島佰男注か：胃・十二指 腸潰瘍に対する私の治㞠方針一小範囲切除術を中 心に一。手術 $27: 40-47,1973$

30）大西淳夫, 鋳谷周三, 児玉博行ほか：胃・十二指腸 潰瘍における術式別にみた術後の减酸効果・胃内 容排泄時間および遠隔成績について，日消外会誌 $11: 947-953,1978$

31）渡部洋三, 近藤序一郎, 加藤弘一：術後の愁訴およ び障害一男内容停滞一臨外 $36: 1715-1721$, 1981

32) Rosati I, Serantoni C, Ciani PA: Extended selective proximal vagotomy : Observations on a variant in technique. Chir Gastroenterol 10 : 33-37, 1976 